\title{
YEASTS ISOLATED FROM DIFFERENT EUROPEAN DRY-SAUSAGES IN THE COURSE OF RIPENING
}

\author{
M. C. LOPEZ ${ }^{\mathrm{a}}$, L. M. MEDINA ${ }^{\mathrm{a}}$, M. J. LINARES ${ }^{\mathrm{b}}$ and R. JORDANO ${ }^{\mathrm{a}, *}$ \\ ${ }^{a}$ Departamento de Bromatología y Tecnología de los Alimentos. Universidad de Córdoba, \\ Campus de Rabanales, E-14071 Córdoba. Spain \\ ${ }^{\mathrm{b}}$ Departamento de Microbiología (Microbiología Médica), Facultad de Medicina, \\ Av. Menéndez Pidal, s/n, E-14071 Córdoba. Spain
}

(Received: 10 January 2000; accepted: 18 September 2000)

The evolution in counts of yeasts from six lots of different dry-sausages produced in three European Union (EU) countries (France, Italy and Spain) is tested. Each lot was analyzed in three phases of their production: fresh product, first staged drying and final product. Three samples were analyzed in each test. Counts of yeasts during the ripening process showed an irregular evolution. Regarding the species isolated, the most frequent ones belonged to genera Candida (C. albicans, C. famata, C. guillermondii, C. krusei, C. parapsilosis, C. stellatoidea, C. zeylanoides.), Trichosporon (T. capitatum, T. beigelli), Rhodotorula and Geotrichum (G. candidum).

Yeasts are microorganisms widely distributed in the natural media (ground, air, water and plants). Also, they are part of the normal biota of milk (sometimes counts of $10^{4} \mathrm{cfu} \mathrm{g}^{-1}$ can be found) and some species can grow on cheeses reaching $10^{8}-10^{9}$ cfu g $^{-1}$ counts (BOISSONNET et al., 1994).

Occurrence of yeasts in fermented meats has been scarcely studied in spite of being one of the microbial groups that, together with lactic acid bacteria (LAB), micrococci and moulds, participate in the fermentation processes (BACUS, 1986; LÜCKE, 1988). Yeasts are indispensable to complete the normal ripening process (LEISTNER, 1992), because of their important lipolytic and proteolytic capacity that leads to the development of the flavour (FOURNAUD, 1976). Furthermore, yeasts have a high $\mathrm{O}_{2}$ consumption which suppose a redox potential decrease. This contribute to a rapid

* To whom correspondence should be addressed:

Departamento de Bromatología y Tecnología de los Alimentos, Campus Universitario

Rabanales. Edificio C-1 Anexo. Ctra. N IV Km 396.A, E-14071 Córdoba. Spain

Phone: +34 957 212006; Fax: +34 957212000

E-mail: bt1josar@lucano.uco.es

al1mecal@uco.es 
reddening of dry-sausages. Also, yeasts produce catalase, inhibiting the rancidity process (LEISTNER, 1995). Because of this reason organisms such Debaryomyces hansenii, Debaryomyces klockeri and Candida famata are included in sausages as starters (HUGAS et al., 1992; ROCABAYERA, 1992). Generally, the growth of this fungal biota occurs during the first three weeks, with counts of $10^{3}-10^{4} \mathrm{cfu} \mathrm{g}^{-1}$ (LARPENTGOURGAUD et al., 1993).

The enzymatic activity of yeasts contribute to the production of aromatic compounds that are desirable in dry-sausages. These compounds are by-products of the lipid and protein degradation. However, an error in controlling the growth of these microorganisms can lead to the development of undesirable flavours (METAXOPOULUS et al., 1996).

In the raw meat both molds and yeasts are always present with low numbers but they can compete with bacteria if the meat surface is dried out (DILLON \& BOARD, 1991). In the same way, counts of yeasts in meat can increase and, eventually become the predominant organisms during the storage period under refrigerated conditions. Yeasts can be found both in the meat surface as in the interior, although their main location is the exterior of the product (JESSEN, 1995) due to the high oxygen requirement of these microorganisms. However, at the beginning of the ripening period they can be inside the product (LEISTNER, 1992).

In processed meats (as dry-sausages) the yeasts most frequently isolated belong to the genera Debaryomyces, Trichosporon and Candida (VILJOEN et al., 1993). Regarding to the first, species such $D$. hansenii, capable of growing under conditions of $24 \% \mathrm{NaCl}$ and $a_{w} 0.65$ are included (JAY, 1996). D. hansenii have no activity on nitrates and it is aerobic. The activity of this organism in dry-sausages depends in a great measure on the presence or absence of other starter cultures. When directly inoculating to the meat $10^{6}-10^{7} \mathrm{cfu} \mathrm{g}^{-1}$, the activity of yeasts is preferably observed at the surface of the sausage. This activity expedites the oxygen consume and it has repercussion on the coloration of external surface. Also, the appearance of a characteristic flavour that is especially desirable in Italian dry-sausages is favored (CORETTI, 1977). Other expected advantage is the catalase production which can delay the appearance of rancidity (LEISTNER, 1995).

According to GEHLEN and co-workers (1991) when yeasts are used as starters in combination with micrococci and lactic acid bacteria, better results are obtained. The yeasts effect depends on a great extent on the occurrence or absence of other starters. Only yeasts lead to an increase in the ammonia content and a pH decrease (JENSSEN, 1995). On the other hand, it is necessary to add microorganisms with a strong nitratereducing activity, because of the inhibitory effect of yeasts on staphylococci which occur in meat in a natural way (GEHLEN et al., 1991). 
The aim of this paper is to study the evolution of the counts of yeasts and to identify which species participate in the ripening process of six types of dry-sausages produced in three countries belonging to the European Union (EU): Italy, France and Spain.

\section{Material and methods}

\subsection{Sampling}

Fifty-four samples from six lots (Table 1) corresponding to six types of drysausages produced by manufacturers from three countries belonging to EU (Italy, France and Spain) have been tested. Each lot was analyzed in three phases of their production: at process start, at the completion of the first drying stage and as end product. Three samples were analyzed in each test. A number of colonies equivalent to the square root of the total counted were isolated to be identified.

\subsection{Yeasts count and identification}

The $10 \pm 1 \mathrm{~g}$ sample was homogenized with $90 \mathrm{ml}$ of $0.1 \%$ bacto-peptone (Difco) in buffered sterile water $(\mathrm{pH}$ 7.2). Further dilutions were made as required. The yeast count was verified on acidified Potato Dextrose Agar (PDA, Difco Laboratories, Detroit, MI) at 20 to $25^{\circ} \mathrm{C}$ for 5 to 7 days, according to the Compendium of Methods for the Microbiological Examination of Foods (APHA, 1976). The results were expressed as log colony forming units (cfu) per gram of sample.

Table 1

Description of the types of the dry-sausages analyzed ( $n=162)$

\begin{tabular}{|c|c|c|c|c|c|c|}
\hline Types & $\begin{array}{c}A \\
(\mathrm{n}=27)^{\mathrm{a}}\end{array}$ & $\begin{array}{c}\mathrm{B} \\
(\mathrm{n}=27)^{\mathrm{a}}\end{array}$ & $\begin{array}{c}\mathrm{C} \\
(\mathrm{n}=27)^{\mathrm{a}}\end{array}$ & $\begin{array}{c}\mathrm{D} \\
(\mathrm{n}=27)^{\mathrm{a}}\end{array}$ & $\begin{array}{c}E \\
(n=27)^{a}\end{array}$ & $\begin{array}{c}\mathrm{F} \\
(\mathrm{n}=27)^{\mathrm{a}}\end{array}$ \\
\hline $\begin{array}{l}\text { External diameter }(\mathrm{mm}) \\
\text { Casing }\end{array}$ & $\begin{array}{c}55-60 \\
\text { natural }\end{array}$ & $\begin{array}{c}90 \\
\text { artificial }^{\mathrm{b}}\end{array}$ & $\begin{array}{c}55-60 \\
\text { natural }\end{array}$ & $\begin{array}{c}100 \\
\text { natural }\end{array}$ & $\begin{array}{c}50-55 \\
\text { natural }\end{array}$ & $\begin{array}{c}80 \\
\text { artificial }^{\mathrm{b}}\end{array}$ \\
\hline Grinding size (mm) & 8 & 3.5 & 7 & 7 & 5 & 5 \\
\hline Duration of ripening $^{\mathrm{c}}$ (days) & 15 & 60 & 30 & 60 & 15 & 30 \\
\hline
\end{tabular}

a 3 lots $x 3$ samplings $x 3$ replicates

${ }^{b}$ Collagen

${ }^{c}$ Different commercial starters were added 
For identification, the yeasts-type microorganisms were primarily classified following simple microbial criteria, such as macro- and microscopic aspects, the formation of germinal tube and the production of chlamidospores (CASAL \& LINARES, 1981). Further, the identification follows biochemical criteria such sugars assimilation, by using the API 20C Auxonogram System (La Balme Les Grottes-38390 MontalieuVercieu, France) or by urease test (BARNETT et al., 1990). Also, we used the chromogenic medium CHROMagar Candida (ODDS \& BERNAERTS, 1994) which permits the differentiation between several species of yeasts of great importance in clinical microbiology. This medium is based on the contrast of colors of the colonies developed due to reactions between the species-specific enzyme and a substratum with chromogenic properties (LINARES et al., 1996).

\section{Results and discussion}

The counts of yeasts during the ripening process are summarized in Table 2 .

A regular evolution in these counts during the period studied is not observed. Thus, the lowest numbers were found in the second and third test, for lots $\mathrm{A}$ and $\mathrm{B}$ respectively. In the cases of lots $\mathrm{C}$ and $\mathrm{D}$, the extreme numbers were reached in fresh products. For lots $\mathrm{E}$ and $\mathrm{F}$, this fungal biota increased during the ripening process, and the highest numbers were found in the final product.

Table 2

Counts ${ }^{a}$ of yeasts in the course of ripening of three European dry-sausages

\begin{tabular}{|c|c|c|c|c|c|c|}
\hline & \multicolumn{2}{|c|}{ Lot $A(n=9)$} & \multicolumn{2}{|c|}{ Lot B (n=9) } & \multicolumn{2}{|c|}{ Lot $C(n=9)$} \\
\hline & Mean & Rank & Mean & Rank & Mean & Rank \\
\hline Process start & 3.81 & $3.68-3.89$ & 2.36 & $2.32-2.40$ & 3.94 & $3.48-4.20$ \\
\hline First stage drying & 4.74 & $4.57-4.85$ & 2.29 & $1.00-2.64$ & 3.77 & $3.61-3.88$ \\
\hline \multirow[t]{3}{*}{ End products } & 3.78 & $3.49-4.04$ & 3.47 & $2.75-3.74$ & 3.47 & $2.76-3.71$ \\
\hline & \multicolumn{2}{|c|}{ Lot $D(n=9)$} & \multicolumn{2}{|c|}{ Lot $E(n=9)$} & \multicolumn{2}{|c|}{ Lot F (n=9) } \\
\hline & Mean & Rank & Mean & Rank & Mean & Rank \\
\hline Process start & 4.00 & $3.60-4.28$ & 4.16 & $4.00-4.30$ & 3.89 & $3.60-4.04$ \\
\hline First stage drying & 2.00 & $1.00-2.93$ & 5.20 & $4.96-5.30$ & 5.14 & $4.72-5.31$ \\
\hline End products & 2.55 & $2.32-2.85$ & 5.33 & $5.03-5.51$ & 5.49 & $4.74-5.85$ \\
\hline
\end{tabular}

${ }^{\text {a }}$ Expressed as $\log \mathrm{cfu} \mathrm{g}^{-1}$ 
According to LARPENT-GOURGAUD and co-workers (1993) and BOISSONET and co-workers (1994), in sausages yeasts multiply during the ripening process (three weeks) up to counts of $10^{3}-10^{4} \mathrm{cfu} \mathrm{g}^{-1}$, what we have found in most of the samples studied. Also, SAMELIS and co-workers $(1993 ; 1994)$ suggest that yeasts, which exceed $10^{5} \mathrm{cfu} \mathrm{g}^{-1}$ during late ripening, may contribute in a decisive way to the good flavor and aroma of certain batches of sausages. In our work, this counts only occur in two lots (E and F).

In a work dealing with Italian dry-sausages, a similar variability in yeasts counts to that found in our work was reported, and the maximum was $\log 5.6 \mathrm{cfu} \mathrm{g}^{-1}$ (SSICA, 1992).

JAY and MARGITIC (1981) reported counts of yeasts similarly high in raw meat $\left(\log 7 \mathrm{cfu} \mathrm{g}^{-1}\right)$. SAMELIS and co-workers $(1993 ; 1994)$ consider the yeasts counts higher than $\log 5 \mathrm{cfu} \mathrm{g}^{-1}$ as contributing in a decisive way to the characteristic flavour of this type of products.

Most of the consulted references (SMith \& PALUMBo, 1973; Palumbo et al., 1976; DomínGUEZ et al., 1989; SAMELIS et al., 1994 and DAOUDI et al., 1995) reported that yeasts are always present in high numbers $\left(>\log 5 \mathrm{cfu} \mathrm{g}^{-1}\right)$ in these products. Regarding to this aspect, MCCARTHY and DAMAGLOU (1996) think that high yeasts counts in dry-sausages can be a hazard, above all if sulfites are used as additive. These compounds inhibit the growth of most of the bacteria, except for Gram-positive ones and yeasts, becoming the last as dominant biota.

In spite of the important role of yeasts in this type of dry-sausages biota, neither of the legislation of the countries involved (Italy, France and Spain) include it as microbial criterion.

The species isolated belong to four genera: Candida, Trichosporon, Rhodotorula and Geotrichum. The greater incidence corresponds to the genus Candida from which a higher number of species was isolated. From lots A and B, C. albicans, C. famata, C. guillermondii, C. krusei, C. parapsilosis and C. zeylanoides were isolated; Trichosporon capitatum and Rhodotorula were detected in a low percentage. From lots $\mathrm{C}$ and D, besides of some Candida spp. (C. famata, C. parapsilosis, C. stellatoidea and C. zeylanoides), Trichosporon beigelli and Geotrichum candidum were also identified in a high percentage. In the samples correspondent to lots $\mathrm{E}$ and $\mathrm{F}$, the predominant genera were Candida (C. famata, C. guillermondii and C. krusei) and Rhodotorula. T. beigelli was also identified (Table 3 ). 
Table 3

Classification and distribution ${ }^{a}$ of yeasts isolated from six lots of sausages

\begin{tabular}{lcccccc}
\hline & \multicolumn{7}{c}{ Lot } & & \\
\cline { 2 - 6 } & $\mathrm{A}$ & $\mathrm{B}$ & $\mathrm{C}$ & $\mathrm{D}$ & $\mathrm{E}$ & $\mathrm{F}$ \\
\hline Candida albicans & 0 & 18 & 0 & 0 & 0 & 0 \\
Candida famata & 26 & 27 & 40 & 34 & 25 & 25 \\
Candida guillermondii & 17 & 9 & 0 & 0 & 0 & 25 \\
Candida krusei & 33 & 0 & 0 & 0 & 25 & 25 \\
Candida parapsilosis & 0 & 9 & 20 & 0 & 0 & 0 \\
Candida stellatoidea & 0 & 0 & 20 & 0 & 0 & 0 \\
Candida zeylanoides & 8 & 27 & 20 & 0 & 0 & 0 \\
Trichosporon beigelli & 8 & 0 & 0 & 33 & 25 & 0 \\
Trichosporon capitatum & 0 & 9 & 0 & 0 & 0 & 0 \\
Rhodotorula rubra & 0 & 0 & 0 & 0 & 0 & 25 \\
Rhodotorula sp. & 8 & 0 & 0 & 0 & 25 & 0 \\
Geotrichum candidum & 0 & 0 & 0 & 33 & 0 & 0 \\
\hline
\end{tabular}

${ }^{\text {a }}$ Expressed as percentage $(\%)$

On opposite to some authors (VILJOEN et al., 1993; METAXOPOUlOS et al., 1996) we have not isolated species of the genus Debaryomyces in the teleomorphic form, which is abundant in this type of products. On the other hand, C. famata, considered an anamorphic species of $D$. hansenii (BARNETT et al., 1990) has been detected. LARPENTGOURGAUD and co-workers (1993), on different types of french sausages, isolated yeasts belonging to the genera Pichia and Candida, but they did not detect (like us) Debaryomyces. These authors report $D$. hansenii as the most frequent flavouring yeast, although they consider that in sausages that role can be done by other species. Also, other authors reported C. famata as one of the most frequently isolated yeasts in German (SMITH \& HADLOK, 1976), Italian (GRAZIA et al., 1989) and Greek (METAXOPOULOS et al., 1996) sausages. BOISSONNET and co-workers (1994) studied two types of sausages, one handmade and the other one of semi-industrial production. They noted that C. famata was absent in the last type of production, while in the handmade one the percentages were similar to those found in our work.

Other species belonging to Candida are also frequently associated with processed meats. Thus, C. zeylanoides has been isolated from pork sausages (DALTON et al., 1984; VILJOEN et al., 1993), ham (DILLON, 1988), dry-sausages (LARPENT-GOURGAUD et al., 1993; BoIsSONNET et al., 1994) and salami (METAXOPOUlos et al., 1996). C. guillermondii and C. parapsilosis have been isolated from fermented meats (LEISTNER \& BEM, 1970; COMI \& CANTONI, 1980) and C. krusei from salami (METAXOPOUlOs et al., 1996). 
C. zeylanoides and C. famata have a high lipolytic activity. Although C. zeylanoides can produce disagreeable flavors, it can be sometimes interesting because of its greater and faster lipolytic activity. Both species are of interest in the development of aroma in sausages (BOISSONNET et al., 1994).

According to JAY (1996), the most ubiquitous genera of yeasts in raw meat belong to Candida and Rhodotorula, as well as Debaryomyces, Saccharomyces and Trichosporon in cured meats. In the present work we have isolated two species belonging to this last genus (Trichosporon beigelli and Trichosporon capitatum), although in low percentages. In a paper dealing with the proteolytic activity of different species and strains of yeasts isolated from cheeses, SCHMIDT and co-workers (1993) found a great heterogeneousness as far as proteolytic activity is concerned. On this way, T. beigelii has an important proteolytic activity but a lower lipolytic activity. On the other hand, DENNIS \& BUHAGIAR (1980) consider yeasts as the main responsible for lipolytic activity in foods, but only a few of them show proteolytic activity, among them T. beigelii (EKLUND et al., 1965).

Regarding to genus Rhodotorula LARPENT-GOURGAUD and co-workers, (1993) among other authors have also detected it in French dry-sausages, in a low incidence.

Some authors (MEISEL et al., 1989; GEHLEN et al., 1991) reported that selected strains of $D$. hansenii have an inhibitory effect on Staphylococcus aureus. This effect was attributed to a decrease in the $\mathrm{O}_{2}$ level due to yeasts, and enhanced by lactic acid bacteria and micrococci as starter cultures.

\section{Conclusion}

It is necessary to emphasize that the isolated species belonging to the genera Candida, Trichosporon, Rhodotorula and Geotrichum, are widely distributed in the environment and they can behave as opportunist microorganisms. From this point of view, they could origin human infections of different location and importance, generally associated with patients with reduced immune system, like the administration of antitumoral and inmunosuppressors medicaments, radiation treatments, diagnostic operations and aggressive therapies (catheters, probes...), parenteral feeding, organs transplanting, AIDS infection and drug addiction (CRISSEY \& LANG, 1995).

The work reported here was carried out in the course of the DRIP project. This project is partially funded by the FAIR Programme of the Commission of the European Communities (project number 96-1220). This paper represents the authors' point of view and does not necessarily reflect that of the DRIP Consortium. 


\section{References}

APHA (AMERICAN PUBLIC HEALTH ASSOCIATION) (1976): Compendium of methods for the microbiological examination of foods. American Public Health Association, Washington (USA).

BACUS, J. N. (1986): Fermented meat and poultry products. -in: PEARSON, A. M. \& DUTSON, T. R. (Eds) Advances in meat research: Meat and poultry microbiology, Vol. 2, Macmillan, London, p. 123.

BARNETT, J. A., PAYNE, R. W., \& YARROW, D. (1990): Yeast: Characteristics and identification. (2nd ed.) Academic Press New York, p. 123.

Boissonet, B., Callon, C., LARPENT-Gourgaud, M., Michaud, O., Sirami, J. \& BOnNIN, P. (1994): Isolement et sélection des levures lipolytiques a partir de saucissons secs fermentés. (Isolation and selection of lipolytic yeasts from dry-fermented sausages.) Viandes Prod. Carnés, 15(2), 64-67.

CASAL, M. \& LINARES, M. J. (1981): The comparison of six media on chlamidospora production by Candida albicans. Mycopathologia, 76, 125-128.

COMI, G. \& CANTONI, C. (1980): I lieviti in insaccati crudi stagionati. (Yeasts in dry-sausages.) Ind. Alim., $19,857$.

CORETTI, K. (1977): Starterkulturen in der Fleischwirtsschaft. Fleischwirtsch., 57, 386-394.

CRISSEY, J. T. \& LANG, H. (1995): Manual of medical mycology. Blackwell Science, London.

DALTON, H. K., BOARD, R. G. \& DAVENPORT, R. R. (1984): The yeasts of British fresh sausage and minced beef. Ant. van Leeuwenhoek, 50, 227-248.

DaOUdi, A., Stolle, F. A., BelemLIH, A., ZAMBOU, H. R. \& EisGRUBER, H. G. (1995): Hygienic quality and shelf life of a Moroccan cooked (Kosher) sausage. $J$. Fd Prot., 58, 182-185.

DENNIS, C. \& BUHAGIAR, R. W. M. (1980): Yeast spoilage of fresh and processed fruits and vegetables. -in: SKINNER, F. A., PASSMORE, S. M. \& DAVENPORT, R. R. (Eds) Biology and activities of yeasts. Academic Press, London, pp. 123-133.

DILLON, V. M. (1988): Yeasts and moulds associated with meat and meat products. -in: DILLON, V. M. The microbiology of meat and poultry. London Blackie Academic and Professional, pp. 85-117.

DILLON, V. M. \& BOARD, R. G. (1991): Yeasts associated with red meats. J. appl. Bact., 71, 93-108.

DOMINGUEZ, M. C., GUTIERREZ, L. M., LOPEZ, A., SECO, F., ZUMALACARREGUI, J. M. (1989): Evolución de los principales grupos de microorganismos durante la maduración del chorizo de León. (Evolution of the main microbiological groups during the ripening of Leon's "chorizo".) Alimentaria, Jan-Feb, 11-15.

EKLUND, M. W., SPINELLI, J., MIYAUCHI, D. \& GRONINGER, H. (1965): Characteristics of yeasts isolated from irradiated Pacific crab meat. Appl. Microbiol., 13, 985-990.

GRAZIA, L., SUZZI, G., ROMANO, P. \& GIUDICI, P. (1989): The yeasts of meat products. Spec. Suppl. Yeast, $5, \mathrm{~S} 495$.

FOURNAUD, J. (1976): La microbiologie du saucisson sec. (Microbiology of dry-sausages.) L'alimentation et la Vie, 64, 2-3, 82-91.

GEHLEN, K. H., MEISEL, C., FISHER, A. \& HAMMES, W. P. (1991): Influence of the yeast Debaryomyces hansenii on dry sausage fermentation. Proc. 37th Int. Congr. Meat Sci. Technol., Kulmbach, pp. 871-876.

HugAS, M., GARRIGA, M. \& MONFORT, J. M. (1992): Developing microbial cultures as starters for meat processing. -in: SMULDERS F. J. M., TOLDRÁ, F., FLORES, J. \& PRIETO, M. (Eds), New technologies for meat and meat products. ECCEAMST, Utrecht, pp. 71-90.

JAY, J. M. (1996): Modern food microbiology. Chapman \& Hall, New York, pp. 33, 70-71.

JAY, J. M. \& MARGITIC, S. (1981): Incidence of yeasts in fresh ground beef and their rations to bacteria. J. Fd Sci., 46, 648-649.

JESSEN, B. (1995): Starter cultures for meat fermentation. -in: CAMPBELL-PLATT, G. \& COOK, P. E. (Eds), Fermented meats. Chapman \& Hall, Glasgow, pp. 130-159. 
Larpent-Gourgaud, M., Michaux, O., CAllon, C., Brenot, O., SiRAMi, J., BOnNIN, P. \& BoissonNet, B. (1993): Etude comparée des flores d'aromatisation de saucisson de fabrication industrielle ou artisanale. (Comparative study on flavouring microflora of dry-sausages handmade or industrially processed.) Viandes Prod. Carnés, 14, 23-27.

LEISTNER, F. (1992): The essentials of producing stable and safe raw fermented sausages. -in: SMulders, F. J. M., TOldRÁ, F., FlORES, J. \& PRIETO, M. (Eds), New technologies for meat and meat products. ECCEAMST, Utrecht, pp. 1-21.

LEISTNER, L. (1995): Stable and safe fermented sausages world-life. -in: CAMPBELl-PlATT, G. \& COOK, P. E. (Eds), Fermented meats. Chapman \& Hall, Glasgow, pp. 160-175.

LEISTNER, L. \& BEM, Z. (1970): Vorkommen und Bedeutung von Hefen bei Pokelfleischwaren. Fleischwirtsch., 50, 350 .

LinARES, M. J., SOliS, F., RODRIGUEZ, F. C., CASAL, M. (1996): Levaduras: Crecimiento en CHROMagar Candida. (Yeasts: growth on CHROMagar Candida). VII Congreso Nacional de la Sociedad Española de Enfermedades Infecciosas y Microbiología Clínica. Torremolinos, 24/14. 186.

LÜCKE, F. K. (1988): Microbiological processes in the manufacture of dry-sausage and raw ham. Fleischwirtsch. inter., 2, 23.

MCCARTHY, J. A. \& DAMAGLOU, A. P. (1996): The effect of substrate on the radiation resistance of yeasts isolated from sausage meat. Letters appl. Microbiol., 22, 80-84.

Meisel, C., GeHLEN, K. H., Fischer, A. \& HAMMES, W. P. (1989): Inhibition of the growth of Staphylococcus aureus in dry-sausages by Lactobacillus curvatus, Micrococcus varians and Debaryomyces hansenii. Fd. Biotechnol., 3, 145.

METAXopOulos, J., StAVROPOUlOS, S., KAKOURI, A. \& SAMElis, J. (1996): Yeasts isolated from traditional Greek salami. Ital. J. Fd Sci., 1, 25-32.

ODDS, F. \& BERNAERTS, R. (1994): CHROMagar Candida, a new differential isolation medium for presumptive identification of clinically important Candida species. J. clin. Microbiol., 32, 1923-1929.

PALumbO, S. A., ZAIKA, L. L., KISSINGER, J. C. \& SMITH, J. L. (1976): Microbiology and technology of the pepperoni process. J. Fd Sci., 41, 12-17.

ROCABAYERA, X. (1992): Composition and industrial production of starter cultures for the meat industry. -in: SMUlders, F. J. M., TOldRÁ, F., FlORES, J. \& PRIETO, M. (Eds), New technologies for meat and meat products. ECCEAMST, Utrecht, pp. 91-108.

SAMELIS, J., AGGELIS, G. \& METAXOPOULOS, J. (1993): Lipolytic and microbial changes during the natural fermentation and ripening of Greek dry sausages. Meat Sci., 35, 371.

SAMElis, J., StAVROPOUluS, S., KAKOURI, A. \& METAXOPOULOS, J. (1994): Quantification and characterization of microbial populations associated with naturally fermented Greek dry salami. Fd Microbiol., 11, 447.

SCHMIDT, J. L., ROUGER, C., DIEZ, M. \& LENOIR, J. (1993): Activites biochimiques de levures du genre Candida isolées de fromages de chèvre. Microbiologie-Aliments-Nutrition, 11, 165-182.

SMith, J. L. \& PALUMBO, S. A. (1973): Microbiology of Lebanon Bologna. Appl. Microbiol., 26, 489-496.

SMITH, J. L. \& HADLOK, R. (1976): Hefen und Fleisch: Vorkommen, Systematik und Differenzierung. Fleischwirtsch., 56, 379-384.

SSICA (STAZIONE SPERIMENTALE per L'INDUSTRIA delle CONSERVE ALIMENTARI) (1992): Ricerca sulle caratteristiche chimiche, chimico-fisiche e microbiologiche del salame "Napoli" prodotto nella zona di mugnano del cardinale (Avellino). (Researching on chemical, physico-chemical and microbiological characteristics of "Napoli" dry-sausage.) Camera di Commercio di Avellino, Italia.

Viljoen, B. C., DYKES, G. A., CAllis, M. \& VON HOlly, A. (1993): Yeast associated with Vienna sausage packaging. Int. J. Fd Microbiol., 18, 53-62. 